\title{
Defining Causes OF DeFects AND QuALITY CONTROL POINTS IN THE INDUSTRY OF FURNITURE
}

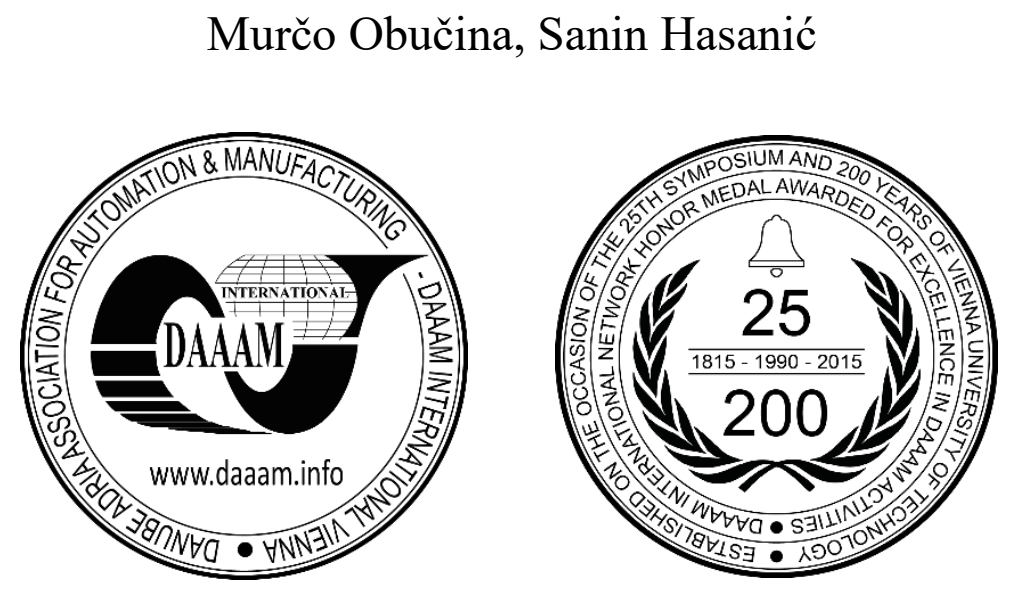

This Publication has to be referred as: Obucina, M[urco] \& Hasanic, S[anin] (2018). Defining Causes of Defects and Quality Control Points in the Industry of Furniture, Proceedings of the 29th DAAAM International Symposium, pp.03880393, B. Katalinic (Ed.), Published by DAAAM International, ISBN 978-3-902734-20-4, ISSN 1726-9679, Vienna, Austria

DOI: $10.2507 / 29$ th.daaam.proceedings.056

\begin{abstract}
Research of defects in the production of massive furniture, their classification and determination of spots of strengthened control represents the condition of survival on the market and the way of meeting customers' demands. Further systematisation, determination of defects and their presentation using the tools of quality control enables us to have clearer and transparent observation of cause-and-effect relationship (causal link) and to early define further steps for dealing with possible non-harmonization in further production. We get this through Ishikawa diagram where at one spot we have an overview of the potential causes of a problem resulting in appearance of defect in process of production. Based on that, we determine the Control Points as spots showing the increased appearance of defects.
\end{abstract}

Keywords: defects; Ishikawa diagram; tool of quality control; Control Point

\section{Introduction}

This paper work is referred to the research of appearance of defects and causes in the production of massive furniture, influence of technology on defect appearance and determination of quality control points. The research was done in $\mathrm{BiH}$ companies where defects were registered per type of defect and frequency of their appearance. By selection of certain technological process for each product, we have the use of technological groups (presented in the further text) so it is needed to organized specific control for that product.

Organization of quality control as a separate function in one company and determination of spots, where strengthened control should be applied, is continuous process and depends on determination of needed model of production process and technology chosen for that process. The main goal of this work was to systematize and clearly recognize frequent defects at one spot in the production of furniture. After that it is needed to give an overview of spots of quality control and types of measurement conducted on these spots.

This way would clearly provide spots where the control is to be done and what exactly is to be measured on certain control points. 
The quality control in the industry of furniture of massive wood must be organized in the way to identify as soon as possible non-conformity of the material in order to make corrections. No matter on chosen technological procedure, it is very important to organize quality control in the industry of furniture and to thoroughly conduct:

- $\quad$ entry control, where we conduct:

1. control of wood moisture,

2. quality control of boards and wood (cracks, wood failure, bumps, visual check)

3. dimension control and control of requested tolerance, and

4. control of requested quality of massive boards and other input material.

- control of final dimensions and shape of profile,

- control of accuracy of drilling due to possible problems during montage,

- control of wood finishing,

- control of packing and

- final control.

The project quality can be viewed in different ways. The factor of who assesses the quality, and what is the evaluation based on, is always decisive. However, the bottom line is always determined by customers`or stakeholders` requirements [4]. The research of influencing factors on the quality process in the wood industry was dealt by [1], [3], [6], while determination of technological groups in the industry of furniture was researched by [10]. Determination of technological groups is very important for one company since you are able to make quick respond to customers' demands and demands of the market. The research of defects in the industry of furniture was done by [5], where he made classification of defects, and presentation and systematization of defects in the wood industry was done by [2].

\section{Defining technological groups in the industry of furniture}

The most widely used model for the production of furniture of massive wood must have the organizational structure that will rapidly respond to customers' and markets' demands and it must be efficient in relation to hierarchic organizational structure of production. As an integral part of the structure of one organization in production of furniture technological groups include more mutual connected operations and they divided into:

I. Technological group - Sawing of timbers and boards,

II. Technological group - Machine-processing of components of boards and saw timbers including:

- $\quad$ Planning of components

- Formatting,

- $\quad$ Profile designing - profiling, etc.

III. Technological group- Machine-processing by drilling,

IV. Technological group - Machine-processing by grinding,

V. Technological group - CNC machines,

VI. Technological group- Finishing of components and products, and

VII. Technological group- Montage of components and products.

Nowadays plants (drives) for furniture production are conceptualizes in the sense that they present compromise between CNC technology and classic machines for wood processing. First, second, third and fourth technological group encompass bigger numbers of technologies used for processing of board components and saw timbers of certain constructive and technological shapes. The fifth technological group understands CNC technology and it can function independently but due to reduced productivity in the production where only this production technology is used, the production is completed with the classic production technologies for wood processing. This combination of technologies is the compromise of rational investment in technology from the standpoint of covering the most important technological phases. The sixth and seventh technological group encompass the technology for finishing and montage where certain component and products are processed.

Critical Control Point (CCP) is determined depending on which technological group is prevailing i.e. which technological procedure is for certain product or for product assortment of one furniture production.

Also, spots of control points are determined in correlation to frequency of certain operations for the product assortment in one company and on the basis of quality demands by customers. It is important to emphasize that employment of quality principles and determination of critical points, where quality control is being done, must be defined in the process of conquering the new product itself and respected throughout the product life cycle. From the standpoint of control management it is very important to determine control points as fast as it can be done and with decreased costs of rejects accomplish desirable aim and fulfil the customers' demands. 


\section{Identification of defects for determination of control points}

Constancy of production quality, especially when the furniture is produced in series, enables the industry of massive furniture, while designing the quality management system whose segments or whole production processes are repeated, to focus on those phases of product lifecycle where non-conformity is increased.

Such process validation, in which the process is required to comply with the process window, is accomplished by statistical process control. A way to define and implement the method of process validation is to [8]:

- Develop optimum system parameters by optimization combined with evaluation of the product quality.

- Make a statistical evaluation of the part quality variation over a sufficient amount of production runs with fixed system control parameters utilizing des

- Contructive testing of produced parts to verify that common cause variations are always well within the process window that fulfills the product specification.

- Use statistical process control to ensure the absence of special cause variations in each production run.

- Implement strict quality control on all conditions outside the system control parameters such as raw material quality, operator routines, system maintenance and support systems.

Establishing the principle of quality, at very beginning of developing the new product spots where increased nonconformity of critical control points is noticed, must be identified what requires the special approach to quality management that would be directed toward points where occurrence of defects is most likely. The defect can be occurred in each phase of production process. However, the experience shows that defects in some parts of production process are frequently occurred than in others. Occurrence of defect will result in getting the product which does not meet customer's demands neither normative defined in the process of developing the new product and this product is consider as nonconformity product.

While defining critical control points we cannot exclude the process as the reason for defect occurrence what comes out of assumption that all processes are defined during the process of developing the new product, that production is done with installed and checked technology, agreed materials and the chosen process, itself, can be false and it can bring to non-conformity of product. Defined process where CNC technology is mostly used will bring to reduction of occurrence of non-conformity in the part of machine treatment of piece of furniture in relation to the process where classical machines for wood treatment are used while on another side the productivity will be reduced. Due to this at very beginning of developing the new product and defining the production process it is needed to determine critical control points for that product on the basis of:

- Experience of the previous projects, and

- On the basis of customer's demands which have to be integrated into the product from its own creation.

Defects in the production process are results of production of parts or assembly which do not meet customers' demands, standard requirements and specification built up on that ground. Such products cannot be delivered to customer or adjusted to acceptable quality. Defects on the products itself considered as waste which must be thrown away and repaired what increase the production costs are not the only defects but it includes mistakes in documents, provided false information about product, delay in delivery or making too much of waste during the processing.

During one production cycle defects may appear [5]:

- before processing,

- during the processing, and

- after processing.

Defects caused before the processing are the most commonly related to defects of input materials and defects of nonquality preparation of production i.e, defects caused due to wrong chosen working method, defects of basing work piece, defects on tensioning of work piece, defects on adjusting of machines and defects on making the processing system. These defects occur at the beginning of production process and they can be eliminated during the entry control and better preparation of production.

The entry control will prevent the use of non-conformity material from a warehouse into production and in that way in very early phase the entry of inadequate material will be prevented to come into processing.

The following is the most commonly checked during the entry control of material in the furniture production of massive wood [1]:

- type of material and whether it is in accordance with the requested specification for certain product,

- moisture of material which has to be within limits $8+-2 \%$,

- ordered number of pieces and completeness in order to release product into production,

- $\quad$ accuracy of requested dimension and tolerance and

- other specific demands for certain product that is defined during the preparation of production. 
Defects in production are necessity but the aim of each company is to minimize and identify them as early as possible. Therefore, each company has to organize the control that will present compromise between control of each operation, which is very unfavourable from the point of cots, and the final control that can have major consequences if it is the only way of control. In order to avoid appearance of any defects during the processing and to promptly identify them, the controls on specific spots must be organized and critical control points must be determined depending on technological capability of company and chosen flow of processing. The research completed in this work was done in way to register defects during the process per types and frequency. Doing so, certain control pints were determined which have to be marked. Therefore, during the flow of production we have the following controls that are imposed as logical [2]:

- control of accuracy of cutting measures,

- control of accuracy of making elements of bounds,

- control of grinding quality,

- control of lacquering or oiling quality (surface treatment of wood) and

- control of montage possibilities.

Defects caused after the processing are mostly related to defects of measurement and defects caused as a consequence of uncompleted series of delivery are being checked in the following controls as follows:

- control of packaging and

- $\quad$ final control of delivery.

The most common defects caused during the production have the changeable character due to daily different influences on the production process itself and the major influence on it has the man power. Completed research [6] based on researching of influences among three resources of defects - man power, materials and machines has shown that the major influence on capability of technological approach has the man power $41,2 \%$, materials $38,6 \%$ and machines $20,2 \%$. In our experiment we registered all defects caused on different spots during the production. The overview of conducted measurements on certain control spot are given in the following table:

\begin{tabular}{|c|c|c|c|c|c|c|c|c|}
\hline \multirow{3}{*}{$\begin{array}{l}\text { Defect } \\
\text { Control spot }\end{array}$} & \multicolumn{3}{|l|}{ State } & \multicolumn{5}{|c|}{ Variables } \\
\hline & Documentation & $\begin{array}{l}\text { Respect for } \\
\text { customer's } \\
\text { demands }\end{array}$ & $\begin{array}{l}\text { Control of } \\
\text { working } \\
\text { method }\end{array}$ & Moisture & Dimension & Shape & $\begin{array}{l}\text { Correlation } \\
\text { between } \\
\text { surfaces }\end{array}$ & Surface quality \\
\hline & $\begin{array}{l}\text { FSC } \\
\text { No. of pieces } \\
\text { Patterns }\end{array}$ & & & $8+-2 \%$ & & & & \\
\hline $\begin{array}{l}\text { Entry control } \\
\text { of materials }\end{array}$ & $\mathbf{X}$ & $\mathbf{X}$ & $\mathbf{X}$ & $\mathbf{X}$ & $\mathbf{X}$ & $\mathbf{X}$ & $\mathbf{X}$ & $\mathbf{X}$ \\
\hline $\begin{array}{l}\text { Control of } \\
\text { accurate cuts } \\
\text { of measures }\end{array}$ & & & & & $\mathbf{X}$ & $\mathbf{X}$ & $\mathbf{X}$ & \\
\hline $\begin{array}{l}\text { Control of } \\
\text { accurate } \\
\text { element joints }\end{array}$ & & & & & $\mathbf{X}$ & $\mathbf{X}$ & $\mathbf{X}$ & \\
\hline $\begin{array}{l}\text { Control of } \\
\text { grinding } \\
\text { quality }\end{array}$ & & & & & $\mathbf{X}$ & & $\mathbf{X}$ & $\mathbf{X}$ \\
\hline $\begin{array}{l}\text { Control of } \\
\text { lacquering and } \\
\text { oiling quality }\end{array}$ & & $\mathbf{X}$ & $\mathbf{X}$ & & & $\mathbf{X}$ & $\mathbf{X}$ & $\mathbf{X}$ \\
\hline $\begin{array}{l}\text { Control of } \\
\text { montage } \\
\text { possibilities }\end{array}$ & & $\mathbf{X}$ & $\mathbf{X}$ & & $\mathbf{X}$ & $\mathbf{X}$ & $\mathbf{X}$ & \\
\hline $\begin{array}{l}\text { Control of } \\
\text { packaging }\end{array}$ & & $\mathbf{X}$ & $\mathbf{X}$ & & $\mathbf{X}$ & & & \\
\hline $\begin{array}{l}\text { Final control } \\
\text { of delivery }\end{array}$ & & $\mathbf{X}$ & $\mathbf{X}$ & & $\mathbf{X}$ & & & \\
\hline
\end{tabular}

Table 1. Control spots

Once the process and its boundaries have been clearly defined, brainstorming, Ishikawa diagram or other tools are used to identify as many risks as possible which may threaten the process [7]. 
Our experiment registered all spots with defects where controllers were located who have been introduced and trained for detection and registration of all defects during the production process (Table 1). These defects were systematized and shown through diagram cause-effect model $4 \mathrm{M} 1 \mathrm{E}$, figure 1 , which as a consequence has defect occurrence in production of furniture of massive wood.

Diagram cause-effect is a tool which helps in identification, sorting and representation of possible defects, specific problems or quality characteristics. It graphically presents the relation of input and factors that have influence on output. Very often the diagram is called "fish bone diagram" due to its specific look.

Ishikawa, in his analysis of defect occurrence, has established that there are five major groups of causes and named them 4M1E: machine, method, material, man power (mind power), and environment [3].

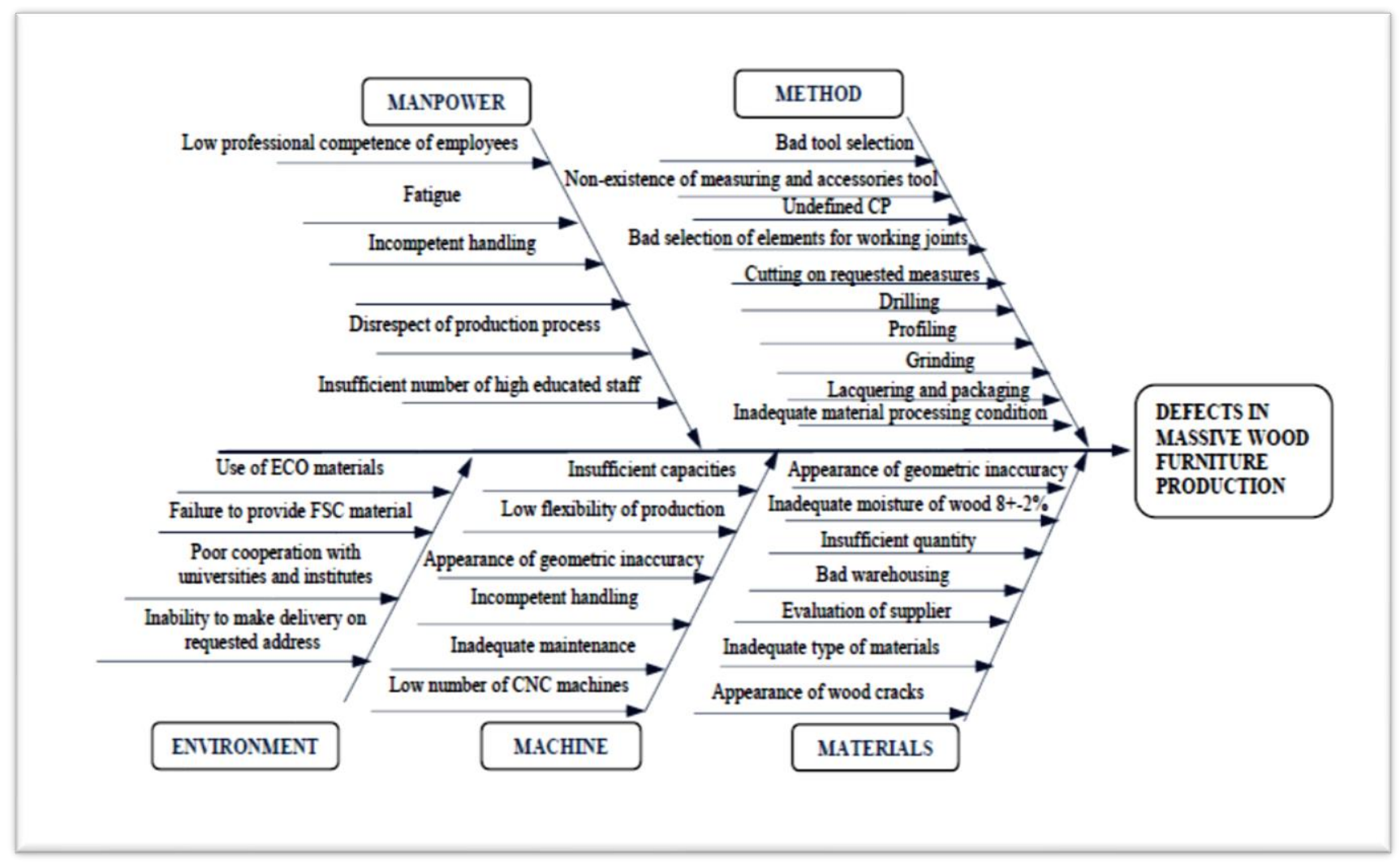

Fig. 1. Cause-effect diagram 4M1E with defect classification

When on the certain level of importing data on diagram all identified causes are exhausted and the logic identification of each branch is determined, we move on the analysis of data which beside the role of directing on basic problems enables determination of major influencing factors in certain cases which as the results provides determination of critical control points. Ishikawa diagram itself is not sufficient for problem solving but it gives guidelines for determination of basic causes and cause-effect relation.

The research and application of mentioned method and conducted analysis of influence of defects resulted in determination of spot of reinforced control where we should take an action and as the result of such action we will get preventive component which will be the source of information on problems before its occurrence.

Control point is a term taken on the basis of experience and most likely it defines suitable spot or process for defect occurrence within one production process which due to its characteristics or experience can represent the spot where the bigger possibility of non-conformity appearance is most likely. It is definitely not a static variable; it changes from one product to another depending on many factors including external and internal influencing factors.

In the case of production of wide range of product assortments, what represents one of survival condition on the market, it is impossible to identify Control Points for each single product but for the certain production spot with increased possibility of non-conformity occurrence must be determined. 
Depending on quality demand, defined in the plan of quality management and application of quality principle starting from acceptable quality principle to the high ones, we have to take care about following when defining Control Points:

- how often non-conformity is occurred and in which number,

- what hazard non-conformity indicates where is needed to provide estimation,

- what is the level of risk of determined non-conformity,

- what are possible consequences of non-conformity and

- what time is needed for recovery in case of non-conformity occurrence.

\section{Conclusion}

Transformation of input data into output ones is undertaken during every process. By optimizing, a manufacturing process is therefore needed to focus on the key or critical sub-process. The key sub-process is related to the manufacturing of the key product contributing to the final value of production at most [9]. Each company should apply its own original solution combining different process using manpower, financial, material and other resources as inputs; constantly check and transform them into original products and services. Since every defect can be defined as the cost, it is very important to determine mechanism of action for each of them. Causes of defect occurrence, intervals of occurrence possibility and basic influencing factors causing those occurrences can be determined through analysis of influences and resulted defects. Clearly shown cause-effect relation and determination of Control Points presents the first steps which one company has to determine in order to prevent non-conformity occurrence in further.

In this work it is shown that it is possible to systematize defects and to determine places and type of controls on these places. Also, within completed wider research, it is shown that depending on technological process, the organization of control in certain measure is changed and it must be adapted to each product separately. The most significant control in the industry of furniture must be at the very beginning of process since it is possible to eliminate the biggest numbers of causes of waste in the further production process. In future works, dealing with similar subject, and as the contribution to the further research, it is necessary to provide quantitative indicators of influence of certain defects on quality process ant to provide an overview of influencing factors on mechanism of activity of certain defects.

\section{References}

[1] Obučina M.; Hasanić S. ;Brdarević S.; Jašarević S.; (2011): Integrated process models of quality management of glued massive panels,Journal of Trends in the development of Machinery and Associated Technology Vol. 17. No.1. ISSN2309-4009, pp.109-112,TMT-University of Zenica

[2] Hasanić S.;Brdarević S.;Obučina M.; (2011) : Monitoring of wood solid panels quality using the cause- and- effect diagram, Development trends in economic and management in wood processing and furniture manufacturing, pp. 51 -56, Proceedings, Kozina, Slovenija,

[3] Obučina M.;Hasanić S., (2012):Integrated process model for wood massive panels production, Annals of DAAAM for 2012 \& Proceedings of the 23rd International DAAAM Symposium, Volume 23, No.1, ISSN 2304-1382.

[4] Goicoechea, I[tziar]\& Fenollera, M[aria], (2012). Quality Management in the Automotive Industry, Chapter 51 in DAAAM International Scientific Book 2012, pp. 619-632, B. Katalinic (Ed.), Published by DAAAMInternational, ISBN 978-3 -901509-86-5, ISSN 1726-9687, Vienna, Austria, DOI:10.2507/daaam.scibook.2012.51

[5] Skakić, D.; ( 1992): Finalna prerada drveta, Mikro knjiga, ISBN: 86-7557-007-4, Beograd 1992.

[6] Greger K, Šegotić K., Grladinović T.,Bičanić K., Perić I.(2013) : Rangiranje kriterija pri utvrđivanju sposobnosti tehnološkog procesa u proizvodnji namještaja, Šumarski list, 5-6, str. 279-285,2013.

[7] Svingerova, M[ichaela] \& Melichar, M[artin] (2017). Evaluation of Process Risks in Industry 4.0 Environment, Proceedings of the 28th DAAAM International Symposium, pp.1021-1029, B. Katalinic (Ed.), Publishe by DAAAM International, ISBN 978-3-902734-11-2,ISSN 1726-9679,Vienna,Austria,DOI:10.2507/28th. daaam.proceedings. 142

[8] Ljungblad, U(lric) (2010):Statistical Process Control Applied to Additive Manufacturing Enables Series Production of Orthopedic Implants, Annals of DAAAM for 2010 \& Proceedings of the 21st International DAAAM Symposium, Volume 21, No. 1, ISSN 1726 -9679ISBN 978-3-901509-73-5, Editor B.Katalinic,Published by DAAAM International, Vienna, Austria, EU, 2010Make Harmony Between Technology and Nature, and Your Mind will Fly Free as a Bird 3rd DAAAM-ICA

[9] Sujova A(ndrea), Marcinekova K(atarina), Hittmar S(tefan) (2017 )Sustainable Optimization of Manufacturing Proces Effectiveness in Furniture Production, Sustainability, MDPI, Open Access Journal, vol. 9(6), pages 1-15, June 2017,

[10] Šuletić, R. (2009) :Primena grupnog koncepta fleksibilne proizvodnje nameštaja, Prerada drveta, str 28-33, Šumarski fakultet u Beogradu, Univerzitet u Beogradu, Beograd. 